\title{
KEDUDUKAN HUKUM BITCOIN SEBAGAI MATA UANG VIRTUAL DI INDONESIA BERDASARKAN UNDANG-UNDANG NOMOR 7 TAHUN 2011 TENTANG MATA UANG
}

\author{
Clara \\ (Mahasiswi Program S1 Fakultas Ilmu Hukum Universitas Tarumanagara) \\ (Email: Clara_the1@yahoo.com)
}

Siti Nurbaiti

(Corresponding Author)

(Dosen Hukum Dagang Fakultas Hukum Universitas Tarumanagara, Meraih Sarjana Hukum dari

Universitas Trisakti, Magister Hukum dari Universitas Tarumanagara, Doktor Hukum dari

Universitas Trisakti)

(Email: nurbaiti_05092000@yahoo.com)

\begin{abstract}
Nowadays people rely on many things in order to do daily activity. As time goes by, global economy has changed and has had significant growth. The form of money has also changed, from only being available in the physical form, such as coins and banknotes, now we have the digital form of money, otherwise known as virtual currency. This paper discusses about the legal status of Bitcoin as virtual currency in Indonesia according to Law Number 7 of 2011 regarding Currency Law. The author examines the problem by using normative legal research methods with descriptive approach. The data was collected from secondary and primary data and is used as supportive research data. The collected data is analysed using qualitative method. The result of this research is the legal status of Bitcoin as virtual currency in Indonesia according to Law Number 7 of 2011 regarding Currency Law has not been regulated yet. Therefore, the government of Indonesia needs to make a specific regulation to regulate Bitcoin in Indonesia.
\end{abstract}

Keywords: Money, Bitcoin, Virtual Currency. 


\section{Pendahuluan}

\section{A. Latar Belakang}

Dewasa ini, manusia membutuhkan banyak bantuan untuk memberikan kemudahan dalam menyelesaikan kegiatannya. Bantuanbantuan ini berupa benda atau barang dan jasa. Definisi benda ini dapat ditemukan pada Pasal 499 Kitab Undang-undang Hukum Perdata. Pada Pasal tersebut, disebutkan bahwa kebendaan ialah, tiap-tiap barang dan tiap-tiap hak, yang dapat dikuasai oleh hak milik. ${ }^{1}$

Pengertian yang paling luas dari perkataan "benda" (zaak) ialah segala sesuatu yang dapat dihaki oleh orang. Ada juga perkataan benda itu dipakai dalam arti yang sempit, yaitu sebagai barang yang dapat terlihat saja. Ada lagi dipakai, jika yang dimaksudkan adalah kekayaan sesorang. Undang-undang membagi benda-benda dalam beberapa macam: ${ }^{2}$

1. Benda yang dapat diganti (contoh: uang) dan yang tidak dapat diganti (contoh: seekor kuda);

2. Benda yang dapat diperdagangkan (praktis tiap barang dapat diperdagangkan) dan yang tidak dapat diperdagangkan atau "di luar perdagangan" (contoh: jalan-jalan dan lapangan umum);

3. Benda yang dapat dibagi (contoh: beras) dan yang tidak dapat dibagi (contoh: seekor kuda);

4. Benda yang bergerak (contoh: perabot rumah) dan yang tak bergerak (contoh: tanah).

Macam-macam benda yang membantu kehidupan manusia pada kehidupan milenial sekarang adalah kendaraan, gadgets, media pembayaran, dan hal lainnya. Seiring dengan perkembangan zaman,

\footnotetext{
${ }^{1}$ Kartini Muljadi dan Gunawan Widjaja, Kebendaan Pada Umumnya, Cetakan ke-1, (Jakarta: Kencana Prenada Media Group, 2003), hal.31.

${ }^{2}$ Subekti, Pokok-pokok Hukum Perdata, Cetakan ke-20, (Jakarta: Intermasa, 1985), hal.60-61.
} 
muncul jenis benda yang lain, yaitu produk digital. Menurut Troy J Strader: ${ }^{3}$

"Digital products are contents goods or services such as software, books, music, movies or financial services that can be digitized and traded on a digital market place. A number of different definitions are used in the literature. Whinston, Stahl, and Choi (1977) described digital products as products that can be digitized and transferred over a digital network."

(Produk digital adalah barang atau jasa seperti perangkat lunak, buku, musik, film, atau jasa finansial yang dapat didigitalisasikan dan diperjualbelikan pada pasar digital. Terdapat beberapa definisi yang berbeda yang digunakan dalam literatur. Whinston, Stahl, dan Choi (1977) mengartikan produk digital sebagai produk yang dapat didigitalisasikan dan ditransfer melalu jaringan digital).

Perkembangan produk digital ini diikuti pula dengan perkembangan berbagai metode pembayaran, seperti pembayaran via PayPal, virtual account, kartu kredit, dan belakangan muncul metode pembayaran baru yang mendapat perhatian publik yaitu alat pembayaran virtual.

Alat pembayaran virtual merupakan serangkaian kode pemograman komputer yang digunakan dalam kegiatan transaksi dalam dunia virtual, berdasarkan bentuknya terdapat 3 (tiga) skema mata uang virtual yaitu: ${ }^{4}$

1. Skema mata uang virtual tertutup

Pada jenis mata uang ini, mata uang hanya berlaku dalam suatu komunitas atau sistem tertentu saja dan tidak dapat dipergunakan diluar komunitas maupun diluar sistem tersebut. Contoh dari skema mata uang virtual tertutup ini adalah mata uang dalam berbagai jenis permainan yang terdapat pada komputer, komputer tablet, maupun telepon genggam. Pemain akan membayar sejumlah uang tertentu kepada perusahaan pengembang permainan tersebut kemudian pemain akan mendapat mata uang permainan tersebut yang dapat ditukar untuk barang atau jasa yang ada di permainan tersebut.

2. Skema mata uang virtual satu arah

3 Troy J. Strader, Digital Products, Management, Technology, and Practice, (Pennsylvania: Business Science Reference, 2010), hal.87.

${ }^{4}$ European Central Bank, "Virtual Currency Schemes", (European Central Bank, Oktober 2012), hal. 13-14. 
Pada mata uang jenis ini, mata uang virtual ini didapatkan dengan cara menukarkan uang yang sah dan diakui suatu negara seperti Rupiah ke dalam bentuk mata uang virtual yang dapat digunakan untuk membeli barang dan/atau jasa virtual dalam hal tertentu. Jenis mata uang virtual ini juga dapat digunakan untuk membeli barang dan/atau jasa di dunia nyata, contohnya adalah Facebook credits, dengan menggunakan Facebook credits pengguna dapat berbelanja secara online.

3. Skema mata uang virtual dua arah

Pada jenis skema mata uang virtual ini, pengguna dapat menjual dan membeli uang virtual berdasarkan nilai tukar yang berlaku. Kemudian, pengguna juga dapat menggunakan uang virtualnya untuk membeli atau menjual produk virtual mapun produk nyata. Contoh dari skema ini adalah Linden Dollar (Linden\$), di mana pengguna dapat membeli Linden\$ dan menggunakan Linden\$ untuk membeli barang atau jasa tertentu.

Perkembangan yang pesat terjadi pada skema ketiga. Hal ini ditandai dengan kemunculan program komputer yang dinamakan cryptocurrency atau mata uang kripto. Cryptocurrency atau mata uang kripto adalah mata uang digital yang dibuat dan dikelola menggunakan teknik penyandian (enkripsi) canggih yang dikenal dengan istilah kriptografi. Mata uang kripto merupakan salah satu jenis mata uang virtual.

Mata uang kripto ini ditemukan oleh Satoshi Nakamoto. Satoshi merilis perangkat lunak Bitcoin di internet pada bulan Januari 2009 dan menamai mata uang kripto pertama yang muncul dengan sebutan Bitcoin. Terdapat beberapa cara untuk memperoleh mata uang kripto ini, yaitu melalui trading dan mining.

Trading merupakan metode jual-beli mata uang kripto melalui aplikasi jual-beli mata uang kripto. Sedangkang mining merupakan proses pengeluaran daya komputasi untuk memproses transaksi, mengamankan jaringan, dan membuat semua orang dalam sistem 
tersinkronisasi, atas transaksi yang berhasil diselesaikan ini, miner akan mendapatkan upah berupa bitcoin. ${ }^{5}$

Beberapa macam pelopor mata uang kripto yang tengah menjadi fenomena di kalangan masyarakat adalah Bitcoin, Litecoin, Ethereum, Ripple, dan lainnya. ${ }^{6}$ Lantas, apa yang membedakan mata uang virtual ini dengan uang pada umumnya? Uang adalah sesuatu yang secara umum diterima di dalam pembayaran untuk pembelian barang-barang dan jasajasa serta untuk pembayaran utang-utang. Selain itu, uang juga sering dipandang sebagai kekayaan yang dimilikinya yang dapat digunakan untuk membayar sejumlah tertentu utang dengan kepastian dan tanpa penundaan. $^{7}$

Definisi mata uang virtual sendiri diartikan secara berbeda-beda oleh para pengamat. Mengutip dari jurnal yang diterbitkan oleh staf International Monetary Fund: ${ }^{8}$

"Virtual currencies are digital representations of value, issued by private developers and denominated in their own unit of account. Virtual currencies can be obtained, stored, accessed, and transacted electronically, and can be used for a variety of purposes, as long as the transacting parties agree to use them. The concept of Virtual currencies covers a wider array of "currencies," ranging from simple IOUs of issuers (such as Internet or mobile coupons and airline miles), Virtual currencies backed by assets such as gold and "cryptocurrencies" such as Bitcoin."

(Mata uang virtual merupakan representasi digital atas suatu nilai yang diterbitkan oleh pengembang swasta dan didenominasi oleh nilai yang ditentukan oleh mereka. Mata uang virtual dapat diperoleh, disimpan, diakses, dan digunakan untuk transaksi secara elektronik, dan dapat digunakan untuk berbagai macam tujuan lainnya, selama para pihak mempunyai kesepakatan. Konsep mata uang virtual ini meliputi konsep "mata uang" secara luas, mulai dari surat hutang sederhana (contoh: kupon online atau poin penerbangan), mata uang

5 Anonim, "Pertanyaan yang Sering diajukan", https://bitcoin.org/id/faq\#penambangan, diakses pada 10 Februari 2018.

${ }^{6}$ Divya Joshi, "List of Top Virtual Currencies in 2017 and What Differentiates Them", http://www.businessinsider.com/list-top-cryptocurrencies-analysis-comparison-2017-10/?IR=T, diakses pada 10 Februari 2018.

hal.4.

${ }^{7}$ Iswardono SP., Uang dan Bank, Edisi ke-4, (Yogyakarta: BPFE-Yogyakarta, 1991),

${ }^{8}$ IMF Staff, "Virtual Currencies and Beyond: Initial Considerations", (International Monetary Fund, January 2016), hal.7. (Disertai dengan terjemahan bebas dari Penulis.) 
virtual yang "dilindungi" dengan aset berupa emas, dan "mata uang kripto" seperti Bitcoin).

Mata uang yang kita gunakan sehari-hari ini diterbikan oleh Bank Indonesia dan diakui oleh Pemerintah. Berbeda dari mata uang virtual yang terdesentralisasi, mata uang rupiah ini sangat berpengaruh nilainya terhadap status pemerintahan yang sedang berlangsung di Indonesia.

Di Indonesia sendiri, mata uang virtual juga telah berkembang. Beberapa situs jual beli mata uang virtual yang terdapat di Indonesia adalah Bitcoin.co.id (sekarang berubah menjadi Indodax.com) dan Triv.co.id. Kedua situs ini menawarkan jasa jual-beli mata uang virtual dengan live rate.

Pesatnya perkembangan penggunaan Bitcoin di kalangan masyarakat inilah yang mendorong Bank Indonesia mengeluarkan pernyataan nomor 20/4/DKom, yang berisi: ${ }^{9}$

"Bank Indonesia menegaskan bahwa virtual currency termasuk bitcoin tidak diakui sebagai alat pembayaran yang sah, sehingga dilarang digunakan sebagai alat pembayaran di Indonesia. Hal tersebut sesuai dengan ketentuan dalam Undang-Undang No. 7 tahun 2011 tentang Mata Uang yang menyatakan bahwa mata uang adalah uang yang dikeluarkan oleh Negara Kesatuan Republik Indonesia dan setiap transaksi yang mempunyai tujuan pembayaran, atau kewajiban lain yang harus dipenuhi dengan uang, atau transaksi keuangan lainnya yang dilakukan di Wilayah Negara Kesatuan Republik Indonesia wajib menggunakan Rupiah.

Pemilikan virtual currency sangat berisiko dan sarat akan spekulasi karena tidak ada otoritas yang bertanggung jawab, tidak terdapat administrator resmi, tidak terdapat underlying asset yang mendasari harga virtual currency serta nilai perdagangan sangat fluktuatif sehingga rentan terhadap risiko penggelembungan (bubble) serta rawan digunakan sebagai sarana pencucian uang dan pendanaan terorisme, sehingga dapat mempengaruhi kestabilan sistem keuangan dan merugikan masyarakat. Oleh karena itu, Bank Indonesia memperingatkan kepada seluruh pihak agar tidak menjual, membeli atau memperdagangkan virtual currency.

Bank Indonesia menegaskan bahwa sebagai otoritas sistem pembayaran, Bank Indonesia melarang seluruh penyelenggara jasa sistem pembayaran (prinsipal, penyelenggara switching, penyelenggara kliring, penyelenggara penyelesaian akhir, penerbit, acquirer, payment gateway, penyelenggara dompet elektronik,

9 Anonim, "Siaran Pers", http://www.bi.go.id/id/ruang-media/siaran-pers/Pages/ SP_160614.aspx, diakses pada 19 Januari 2018. 
penyelenggara transfer dana) dan penyelenggara Teknologi Finansial di Indonesia baik Bank dan Lembaga Selain Bank untuk memproses transaksi pembayaran dengan virtual currency, sebagaimana diatur dalam PBI 18/40/PBI/2016 tentang Penyelenggaraan Pemrosesan Transaksi Pembayaran dan dalam PBI 19/12/PBI/2017 tentang Penyelenggaraan Teknologi Finansial.

Bank Indonesia sebagai otoritas di bidang Moneter, Stabilitas Sistem Keuangan dan Sistem Pembayaran senantiasa berkomitmen menjaga stabilitas sistem keuangan, perlindungan konsumen dan mencegah praktik-praktik pencucian uang dan pendanaan terorisme."

Pada Tahun 2017, nilai mata uang virtual bitcoin telah menguat lebih dari 1.000 persen. Pada tahun tersebut pula, nilai bitcoin bahkan sempat menembus 11.000 dollar AS atau setara kira-kira Rp 148,5 juta. ${ }^{10}$

Berdasarkan Pasal 2 Ayat (1) dan (2) Undang-Undang Nomor 7 Tahun 2011 tentang Mata Uang, disebutkan bahwa: "Mata Uang Negara Kesatuan Republik Indonesia adalah Rupiah." dan "Macam Rupiah terdiri atas Rupiah kertas dan Rupiah logam." Hal ini menyebabkan mata uang virtual sebagai alat pembayaran bertentangan dengan Undangundang yang berlaku. Tentu dengan lahirnya fenomena seperti ini, timbul masalah hukum seperti tidak adanya kepastian hukum terhadap para pengguna mata uang virtual ini.

Sampai detik ini, Bank Indonesia telah mengeluarkan dua buah Peraturan Bank Indonesia terkait fenomena mata uang virtual ini ini, yaitu PBI Nomor 18/40/PBI/2016 tentang Penyelenggaraan Pemrosesan Transaksi Pembayaran dan Peraturan Bank Indonesia Nomor: 19/12/PBI/2017 tentang Penyelenggaraan Teknologi Finansial. Pada kedua peraturan yang telah diterbitkan oleh Bank Indonesia tersebut tidak terdapat pengaturan mengenai mata uang virtual sebagai produk digital yang dapat diperjualbelikan melalui media internet.

Peraturan Bank Indonesia secara normatif mengatur mengenai pelarangan mengenai larangan penggunaan mata uang virtual dan

\footnotetext{
${ }^{10}$ Sakina Rakhma, "Nilai Terus Menguat, Pengguna Bitcoin Indonesia Meningkat", http://ekonomi.kompas.com/read/2017/12/04/153000626/nilai-terus-menguat-pengguna-bitcoinIndonesia-meningkat, diakses pada 10 Februari 2018.
} 
sejenisnya ini, padahal di kalangan masyarakat, praktek jual-beli mata uang virtual ini menjadi salah satu fenomena yang tengah booming. Ketidakhadiran regulasi mengenai mata uang virtual ini justru menjadi suatu hal yang meresahkan, baik bagi masyarakat, maupun bagi pengusaha-pengusaha yang bergerak di bidang jual-beli mata uang virtual di Indonesia. Dengan berjalannya kegiatan jual-beli mata uang virtual di Indonesia tanpa regulasi, tidak ada lembaga yang dapat bertanggungjawab apabila terjadi hal yang tidak diinginkan di kemudian hari.

\section{B. Perumusan Masalah}

Berdasarkan latar belakang yang telah diuraikan sebelumnya, maka perumusan masalah yang dikaji adalah bagaimana kedudukan hukum Bitcoin sebagai mata uang virtual di Indonesia berdasarkan UndangUndang Nomor 7 Tahun 2011 tentang Mata Uang?

\section{Pembahasan}

Menurut Robertson, uang adalah segala sesuatu yang diterima umum sebagai alat pembayaran barang-barang. Sedangkan R. Sayers mendefinisikan uang sebagai segala sesuatu yang diterima secara umum untuk membayar hutang. Pigou memberikan definisi uang adalah segala sesuatu yang diterima umum untuk dipergunakan sebagai alat penukar. ${ }^{11}$ dan pada Pasal 1 Angka 2 Undang-Undang Nomor 7 Tahun 2011 tentang Mata Uang, disebutkan bahwa Uang merupakan alat pembayaran yang sah.

Uang mempunyai beberapa kriteria yang dapat dijadikan sebagai pedoman, yaitu: ${ }^{12}$

a. Acceptability and Cognizability

Persyaratan utama dari sesuatu menjadi uang adalah diterimanya

\footnotetext{
${ }^{11}$ Pratama Rahardja, Uang dan Perbankan, (Jakarta: Rineka Cipta, 1990), hal. 6.

${ }^{12}$ Iswardono SP., Uang dan Bank, Edisi ke-4, (Yogyakarta: BPFE-Yogyakarta, 1991),
} hal.4-6. 
secara umum dan diketahuinya secara umum. Diterima secara umum serta penggunaan sebagai alat tukar, penimbun kekayaan, standar cicilan utang tumbuh secara luas karena kegunaan (manfaat) dari uang untuk ditukarkannya dengan barang-barang dan jasa-jasa.

b. Stability of Value

Manfaat dari sesuatu yang menjadi uang memberikan adanya nilai uang. Maka diperlukan menjaga nilai uang agar tetap stabil ataupun berfluktuasi secara kecil. Karena, kalau tidak, uang tidak akan diterima secara umum, karena masyarakat mencoba menyimpan kekayaannya dalam bentuk barang-barang yang nilainya stabil. Jika mata uang suatu negara berfluktuasi, nilainya secara tajam, maka masyarakat negara tersebut akan mengurangi fungsinya sebagai alat penukar dan satuan hitung.

c. Elasticity of Supply

Jumlah uang yang beredar harus mencukupi kebutuhan dunia usaha (perekonomian). Ketidakmampuan penyediaan uang untuk mengimbangi kegiatan usaha akan mengakibatkan perdagangan macet dan pertukaran dilakukan seperti pada perekonomian barter, dimana barang ditukar dengan barang yang lain secara langsung. Karena itu Bank Sentral sebagai pencipta uang tunggal harus mampu melihat perkembangan perekonomian yang selanjutnya harus mampu menyediakan uang yang cukup bagi perkembangan perekonomian tersebut. Dan sebaliknya ban sentral harus bertindak dengan cepat seaindainya dirasa uang yang beredar terlalu banyak dibandingkan dengan kegiatan perekonomian, dalam hal ini Bank Sentral harus mengurangi jumlah uang yang beredar. Jadi, kemampuan Bank Sentral dan lembaga-lembaga keuangan yang lain dalam hal penyediaan uang harus dijamin tetap baik (bersifat elastis).

d. Portability

Uang harus mudah dibawa untuk urusan setiap hari. Bahkan transaksi dalam jumlah besar dapat dilakukan dengan uang dalam jumlah (fisik) yang kecil jika nilai nominalnya besar. 


\section{e. Durability}

Dalam pemindahan uang dari tangan yang satu ketangan yang lain, mengharuskan uang tersebut dijaga nilai fisiknya. Kalau tidak, rusak ataupun robek akan menyebabkan penurunan nilainya dan merusak kegunaan moneter dari uang tersebut.

\section{f. Divisibility}

Uang digunakan untuk memantapkan transaksi dari berbagai jumlah. Sehingga uang dari berbagai nominal (satuan/unit) harus dicetak untuk mencukupi/melancarkan transaksi jual-beli. Untuk menjamin dapat ditukarkannya uang satu dengan yang lainnya, semua jenis uang harus dijaga agar tetap nilainya.

Disamping memiliki kriteria, uang juga memiliki beberapa fungsi, yaitu sebagai: ${ }^{13}$

a. Satuan Nilai

Fungsi uang yang pertama dikenal dengan berbagai sebutan, salah satu yang paling umum adalah satuan nilai (unit of value), standar nilai (standard of value), satuan hitung (unit of value), nilai ukur umum (common measure of value), dan nilai denominasi umum (common denominator of value). Semua istilah-istilah ini mewakili satu gagasan yang umum: Satuan moneter berfungsi sebagai satuan terhadap mana nilai dari barang-barang dan jasa-jasa diukur dan dinyatakan. Segera setelah suatu satuan meneter dikembangkan seperti dollar, peso, franc, poundersterling, atau rupiah, maka nilai dari setiap barang atau jasa dapat dinyatakan sebagai suatu harga (price), yang kita artikan sebagai jumlah satuan moneter untuk apa uang ditukarkan.

Praktek pengukuran nilai barang dan jasa dalam unit-unit moneter sangat menyederhanakan masalah pengukuran nilai tukar komoditi di pasar. Seseorang tinggal membandingkan harga-harga relatifnya dalam unit-unit moneter. Misalnya, jika besi kasar berharga Rp 10.000 per

${ }^{13}$ Stephen M. Goldfield dan Lester V. Chandler, Ekonomi Uang dan Bank, (Jakarta: Erlangga, 1990), hal.7. 
seratus kilogram dan jagung berharga $\mathrm{Rp} 2.500$ per keranjang, maka seratus kilogram besi kasar setara dengan 4 keranjang jagung. Praktek ini memudahkan perhitungan.

b. Alat Tukar

Berbagai istilah telah diberikan untuk fungsi uang yang kedua ini, yaitu: alat tukar (medium exchange), perantara pembayaran (medium of payment), alat sirkulasi (circulating medium), dan alat pembayaran (means of payment). Fungsi uang ini dijalankan oleh sesuatu yang umumnya diterima orang dalam pertukaran barang-barang dan jasa. Kenyataan bahwa uang yang seringkali disebut sebagai daya beli yang umum (generalized purchasing power) atau sebagai pembawa kebebasan (bearer of options) menekankan kebebasan pemilih yang dipunyai oleh si pemakai.

c. Standar Pembayaran Tertunda

Segera setelah uang digunakan secara umum sebagai satuan nilai dan alat pembayaran, maka dengan sendirinya ia menjadi unit yang digunakan untuk mengukur pembayaran tertunda atau pembayaran masa depan. Sistem ekonomi modern memerlukan adanya sejumlah besar kontrak dalam bentuk demikian. Kebanyakan kontrak ini berupa kontrak untuk pembayaran pokok hutang dan bunga hutang dan menetapkan pembayaran di masa depan dalam unit-unit moneter. Sebagian di antaranya berlaku untuk beberapa hari atau beberapa bulan, dan banyak pula yang berlaku untuk sepuluh tahun, dan sebagainya.

Uang merupakan suatu standar pembayaran tertunda yang memuaskan hanya jika daya belinya dapat dipertahankan konstan sepanjang waktu, atau kalaupun nilainya berubah, perubahan itu dapat diperkirakan. Jika terjadi deflasi, terutama kalau itu tidak dapat diperkirakan, maka hal ini akan merugikan kelompok-kelompok yang berjanji membayar sejumlah uang tertentu dan memberi keuntungan tak diduga kepada mereka yang menerima jumlah tertentu tersebut.

d. Alat Penimbun kekayaan 
Segera setelah uang digunakan sebagai satuan nilai dan diterima sebagai alat pembayaran, dengan cepat uang itu digunakan secara luas sebagai alat penimbun kekayaan. Sebenarnya, para pemegang uang adalah pemegang daya beli yang berlaku umum yang dapat dibelanjakan sepanjang waktu bila mereka merasa cocok atas sesuatu barang yang ingin mereka beli. Mereka tahu bahwa uang itu akan diterima pada setiap waktu untuk setiap barang dan jasa dan bahwa uang itu akan tetap konstan dilihat dari segi uang itu sendiri.

Dengan demikian uang merupakan alat penimbun kekayaan yang baik yang dapat membayar keperluan mendadak yang tidak dapat diperhitungkan sebelumnya dan terutama untuk melunasi hutanghutang yang ditetapkan dalam nilai uang. Hal ini tidak berarti bahwa uang adalah stabil dan secara keseluruhan merupakan penimbun kekayaan yang memuaskan; Dapat dikatakan demikian, hanya bila daya beli uang tidak menurun. Tentu saja, uang bukan merupakan satusatunya alat penimbun kekayaan. Fungsi ini dapat dilakukan oleh setiap aktiva berharga.

Terdapat berbagai istilah yang telah diberikan untuk fungsi uang sebagai alat tukar, seperti perantara pembayaran (medium of payment) dan alat pembayaran (means of payment). Segera setelah uang digunakan sebagai satuan nilai dan diterima secara umum sebagai alat pembayaran, dengan cepat uang itu digunakan secara luas sebagai alat penimbun kekayaan. Hal ini terjadi karena masyarakat tahu bahwa uang tersebut akan diterima pada setiap waktu untuk setiap barang dan jasa. ${ }^{14}$

Berbicara mengenai uang, tentu dapat dilihat bahwa uang mengalami perkembangan dari waktu ke waktu. Jika dulu uang hanya berbentuk fisik, sekarang terdapat uang dalam bentuk virtual. Seiring perkembangan jaman, muncul pula berbagai cara bagi masyarakat untuk menimbun kekayaannya seperti dengan melakukan jual-beli mata uang virtual sebagai salah satu bentuk investasi yang dapat dicairkan kapan saja. Mata uang virtual dianggap

\footnotetext{
${ }^{14}$ Ibid., hal. 8-9.
} 
oleh masyarakat zaman sekarang sebagai salah satu alternatif untuk menabung.

Mengutip sejarah singkat mengenai beberapa macam mata uang virtual yang ada sekarang dari Ryan Farell: ${ }^{15}$

"Although the concept of electronic currency dates back to the late 1980s, Bitcoin, launched in 2009 by pseudonymous (and still unidentified) developer Satoshi Nakamoto, is the first successful decentralized cryptocurrency. In short, a cryptocurrency is a virtual coinage system that functions much like a standard currency, enabling users to provide virtual payment for goods and services free of a central trusted authority.

Cryptocurrencies rely on the transmission of digital information, utilizing cryptographic methods to ensure legitimate, unique transactions. Bitcoin took the digital coin market one step further, decentralizing the currency and freeing it from hierarchical power structures. Instead, individuals and businesses transact with the coin electronically on a peer-topeer network. It caught wide attention beginning in 2011, and various altcoins - a general name for all other cryptocurrencies post-Bitcoin - soon appeared.

Litecoin was released in the fall of 2011, gaining modest success and enjoying the highest cryptocurrency market cap after Bitcoin until it was overtaken by Ripple on October 4th, 2014. Litecoin modified Bitcoin's protocol, increasing transaction speed with the idea that it would be more appropriate for day-to-day transactions. Ripple, launched in 2013, introduced an entirely unique model to that used by Bitcoin and currently maintains the second highest market capitalization of approximately $\$ 255$ million (2015).

Another notable coin in the evolutionary chain of cryptocurrency, Peercoin, employs a revolutionary technological development to secure and sustain its coinage. Peercoin merges the PoW technology used by Bitcoin and Litecoin along with its own mechanism, proof-of-stake (PoS), to employ a hybrid network security mechanism."

(Meskipun konsep mata uang elektronik telah hadir sejak tahun akhir 1980an, Bitcoin, diluncurkan pada tahun 2009 oleh Satoshi Nakamoto (nama samaran dan belum teridentifikasi), merupakan salah satu mata uang virtual yang terdesentralisasi pertama. Secara singkat, mata uang virtual merupakan sistem pembayaran virtual yang berfungsi hamper sama seperti mata uang pada umumnya, yang mengizinkan penggunanya unruk menyediakan pembayaran virtual atas barang dan jasa dan bebas dari biaya apapun.

Mata uang virtual ini mengandalkan transmisi informasi digital dan menggunakan metode kriptografi untuk memastikan keamanan dan transaksi yang unik. Bitcoin menjadikan pasar uang digital selangkah ebih maju dengan cara menjadikan Bitcoin sebagai mata uang yang terdesentralisasi dan menghapus hierarki "kekuasaan" penerbit mata uang. Sebagai alternatifnya, para pengguna bertransaksi menggunakan mata uang digital diatas sistem "P2P". Hal ini menarik perhatian banyak orang pada awal

15 Ryan Farell, "An Analysis of the Cryptocurrency Industry”, (University of Pennsylvania, May 2015), hal. 2. (Disertai dengan terjemahan bebas dari Penulis.) 
tahun 2011 dan melahirkan berbagai macam Altcoins (sebutan berbagai macam mata uang virtual sesudah Bitcoin.

Litecoin dirilis pada musim gugur tahun 2011 dan pada saat dirilis, Litecoin berhasil meraih kesuksesan dan menjadi mata uang virtual termahal kedua setelah Bitcoin. Namun, pada 4 Oktober 2014, Ripple mengambil alih kesuksesan tersebut. Litecoin memodifikasi protokol Bitcoin, meningkatkan kecepatan transaksi dengan gagasan hal tersebut akan menjadikan transaksi harian menjadi lebih lumrah. Ripple yang dirilis pada tahun 2013, memperkenalkan bentuk mata uang virtual yang sangat unik seperti yang digunakan oleh Bitcoin dan merupakan mata uang virtual termahal kedua dengan total pendapatan kurang lebih 255 juta dolar amerika pada tahun 2015.

Terdapat satu Altcoin lagi yang berkontribusi dalam evolusi perkembangan mata uang virtual ini, yaitu Peercoin. Peercoin mengembangkan revolusi teknologi untuk menembangkan dan mempertahankan eksistensi mata uang virtualnya. Peercoin menggabungkan teknologi Proof of Work yang digunakan oleh Bitcoin dan Litecoin dengan mekanismenya sendiri, yaitu Proof of Stake, untuk menghasilkan mekanisme hibrida atas jaringan keamanan).

Dapat disimpulkan bahwa mata uang virtual ini muncul karena disebabkan oleh kebutuhan masyarakat, terutama komunitas-komunitas virtual. Kemunculan mata uang virtual ini memberikan kontribusi yang positif terhadap inovasi finansial dan alternatif pembayaran bagi masyarakat. Mata uang virtual sendiri memiliki jumlah pengguna yang berkembang pesat dari waktu ke waktu.

Bitcoin merupakan salah satu jenis cryptocurrency atau mata uang kripto. Bitcoin diciptakan oleh Satoshi Nakamoto pada tahun 2009. Satoshi Nakomoto merupakan nama samaran sang pencipta Bitcoin ini. Konsep dari Bitcoin sendiri jauh berbeda dengan mata uang pada umumnya (fiat currency). Bitcoin merupakan salah satu bentuk produk digital yang hanya diperjual-belikan melalui internet dan tidak terdapat bentuk fisik, seperti uang kertas maupun uang logam.

Pada umumnya, mata uang diterbitkan oleh lembaga keuangan negara seperti bank negara. Hal ini menyebabkan mata uang bersifat tersentralisasi. Berbeda dengan mata uang pada umumnya, Bitcoin tidak diterbitkan oleh lembaga manapun di dunia dan hal ini menyebabkan Bitcoin bersifat terdesentralisasi. Pada saat Bitcoin diciptakan, Satoshi telah mendesain 
sedemikian rupa mengenai cara kerja dan jumlah ketersediaan Bitcoin di dunia, yaitu 21 juta Bitcoin.

Berdasarkan penjelasan Pasal 34 huruf a PBI Nomor 18/40/2016, yang dimaksud dengan "virtual currency" adalah uang digital yang diterbitkan oleh pihak selain otoritas moneter yang diperoleh dengan cara mining, pembelian, atau transfer pemberian (reward) antara lain Bitcoin, BlackCoin, Dash, Dogecoin, Litecoin, Namecoin, Nxt, Peercoin, Primecoin, Ripple, dan Ven. Tidak termasuk dalam pengertian virtual currency adalah uang elektronik.

Jika dilihat dari definisi tersebut di Indonesia, Bitcoin dikategorikan sebagai mata uang virtual. Mata uang virtual ini mengalami perkembangan yang semakin pesat dari hari ke hari. Namun, pemerintah Indonesia sampai saat ini belum mengeluarkan aturan main yang jelas terhadap mata uang virtual ini.

Di Indonesia, pionir penjual mata uang virtual secara resmi adalah PT Indodax (sebelumnya bernama PT Bitcoin Indonesia). Penjualan mata uang virtual ini dapat dilakukan melalui situs www.indodax.com (sebelumnya www.bitcoin.id). PT Indodax adalah sebuah perusahaan yang menyediakan jasa pasar online untuk membeli dan menjual Bitcoin di Indonesia menggunakan mata uang Rupiah. Pemilik akun Indodax juga dapat menukarkan Bitcoin Anda ke berbagai digital asset lain seperti Ethereum, Litecoin, Dogecoin, DASH, Ripple, Stellar, XEM, NXT dan Bitshares secara gratis tanpa potongan biaya sedikit pun. ${ }^{16}$

PT Indodax didirikan pada tahun 2013 dan memiliki beberapa kantor cabang di beberapa kota besar di Indonesia, yaitu Jakarta, Surabaya, dan Bali. PT Indodax saat ini dipimpin oleh Oscar Darmawan selaku Chief Executive Officer (CEO). Sampai detik ini, kisaran jumlah pengguna layanan Indodax.com adalah 1,2 juta pengguna.

${ }^{16}$ Indodax, “Apa Itu Indodax.com?”, https://help.indodax.com/apa-itu-indodax-com/, diakses pada 18 Mei 2018. 
Berikut adalah beberapa perbedaan antara mata uang rupiah (fiat currency) dan mata uang virtual:

\begin{tabular}{|l|l|}
\hline \multicolumn{1}{|c|}{ Mata Uang Rupiah } & \multicolumn{1}{c|}{ Mata Uang Virtual } \\
dan uang kertas. & Hanya berbentuk virtual \\
\hline $\begin{array}{l}\text { Bersifat tersentralisasi (diterbitkan } \\
\text { oleh Bank Indonesia) }\end{array}$ & $\begin{array}{l}\text { Bersifat terdesentralisasi (tidak } \\
\text { diterbitkan oleh lembaga moneter } \\
\text { manapun) }\end{array}$ \\
\hline Tidak diketahui jumlah pastinya & $\begin{array}{l}\text { Hanya berjumlah sebanyak 21 juta } \\
\text { Bitcoin. }\end{array}$ \\
\hline $\begin{array}{l}\text { Diperlukan perantara seperti Bank } \\
\text { dalam melakukan transaksi }\end{array}$ & $\begin{array}{l}\text { Transaksi dapat dilakukan sendiri, } \\
\text { tanpa perantara. }\end{array}$ \\
\hline Nilai rupiah bersifat stabil & Nilainya sangat fluktuaktif \\
\hline $\begin{array}{l}\text { Dalam melakukan transaksi, para } \\
\text { pihak dan bank mengetahui identitas } \\
\text { pengguna layanan. }\end{array}$ & $\begin{array}{l}\text { Dalam melakukan transaksi, } \\
\text { identitas pengguna terjamin } \\
\text { kerahasiaannya. }\end{array}$ \\
\hline
\end{tabular}

Dari beberapa perbedaan yang tersebut, dapat dilihat bahwa perbedaan antara mata uang rupiah dan mata uang virtual sangat signifikan. Mata uang virtual yang bersifat terdesentralisasi membuat pemerintah bersikap waspada. Hal ini dapat ditunjukkan dengan diterbitkannya pernyataan nomor 24/D/Kom pada 13 Januari 2018 silam. Pernyataan tersebut dikeluarkan karena pemerintah tidak memiliki autoritas atas peredaran Bitcoin sebagai mata uang virtual yang beredar.

Jika dibandingkan dengan Negara Amerika Serikat, Internal Revenue Service (IRS) atau lembaga yang berwenang untuk mengurus pajak di Amerika Serikatmengeluarkan peraturan sebagai berikut: ${ }^{17}$

"The Internal Revenue Service (IRS) is aware that virtual currency may be used to pay for goods or services, or held for investment. Virtual currency

17 United States Treasury Department, Notice 2014-21, 2014. (Disertai dengan terjemahan bebas dari Penulis.) 
is a digital representation of value that functions as a medium of exchange, a unit of account, and/or a store of value. In some environments, it operates like real currency -- i.e., the coin and paper money of the United States or of any other country that is designated as legal tender, circulates, and is customarily used and accepted as a medium of exchange in the country of issuance -- but it does not have legal tender status in any jurisdiction.

For federal tax purposes, virtual currency is treated as property. General tax principles applicable to property transactions apply to transactions using virtual currency."

(Lembaga Perpajakan sadar bahwa mata uang virtual turut digunakan untuk membayar sejumlah barang dan/atau jasa, atau diperlakukan sebagai investasi. Mata uang virtual merupakan representasi digital dari suatu nilai yang berfungsi sebagai alat tukar, satuan nilai, dan/atau penyimpan nilai. Dalam keadaan tertentu, mata uang virtual dioperasikan seperti mata uang pada umumnya (contoh: uang logam dan uang kertas Amerika serikat dan/atau negara lainnya yang didesain sebagai mata uang yang sah, yang tersikulasi, dan secara khusus dipergunakan dan diterima sebagai perantara pembayaran oleh negara yang menerbitkannya) namun tidak bersifat sebagai mata uang yang sah pada yurisdiksi manapun.

Demi keperluan hukum pajak, mata uang virtual diperlakukan sebagai properti. Ketentuan pajak pada umunya berlaku terhadap seluruh transaksi yang dilakukan denga mata uang virtual ini.)

Berdasarkan peraturan yang dikeluarkan oleh IRS, dapat dikatakan bahwa Amerika Serikat memperlakukan Bitcoin dan mata uang virtual lainnya sebagai properti. Properti tersebut dapat diperjualbelikan secara bebas oleh masyarakatnya berdasarkan harga pasar yang berlaku. Namun, pihak IRS mewajibkan setiap orang untuk membayar pajak atas hasil jual-beli yang diperoleh oleh masyarakat Amerika.

Mata uang virtual ini tentu mempunyai kelebihan dan kekurangannya sendiri. Berikut adalah kelebihan dan kekurangan mata uang virtual:

\begin{tabular}{|c|c|}
\hline Kelebihan & Kekurangan \\
\hline $\begin{array}{l}\text { Lebih praktis karena mata uang } \\
\text { virtual ini dalam penggunaannya } \\
\text { tidak memerlukan otorisasi dari } \\
\text { lembaga keuangan yang berwenang, } \\
\text { seperti bank. }\end{array}$ & $\begin{array}{l}\text { Tidak terdapat regulasi yang jelas } \\
\text { terkait mata uang virtual di } \\
\text { Indonesia }\end{array}$ \\
\hline $\begin{array}{l}\text { Dapat digunakan sebagai salah satu } \\
\text { uang universal yang bisa berlaku di }\end{array}$ & $\begin{array}{l}\text { Dikarenakan nilainya yang tidak } \\
\text { stabil, keberlangsungan mata uang }\end{array}$ \\
\hline
\end{tabular}




\begin{tabular}{|c|c|}
\hline $\operatorname{man}$ & virtual 11 \\
\hline $\begin{array}{l}\text { Identitas pengguna yang terjamin } \\
\text { keamanannya. }\end{array}$ & $\begin{array}{l}\text { Diperlukan teknologi yang canggih } \\
\text { dan mumpuni dalam menjalankan } \\
\text { transaksi mata uang virtual }\end{array}$ \\
\hline $\begin{array}{l}\text { Mengurangi resiko terjadinya } \\
\text { transaksi secara berulang karena } \\
\text { setiap pengguna hanya mempunyai } \\
\text { satu "alamat" saja untuk setiap } \\
\text { transaksi yang akan dilakukan. }\end{array}$ & $\begin{array}{l}\text { Dikarenakan identitas pengguna } \\
\text { layanan mata uang virtual hanya } \\
\text { diketahui melalui "alamat"nya } \\
\text { saja, maka sangat sulit untuk } \\
\text { mengetahui siapa pemilik "alamat" } \\
\text { tersebut. }\end{array}$ \\
\hline $\begin{array}{l}\text { Meminimalisir pencurian identitas } \\
\text { (contoh: pencurian identitas pada } \\
\text { kartu kredit) seperti yang sedang } \\
\text { marak terjadi. }\end{array}$ & 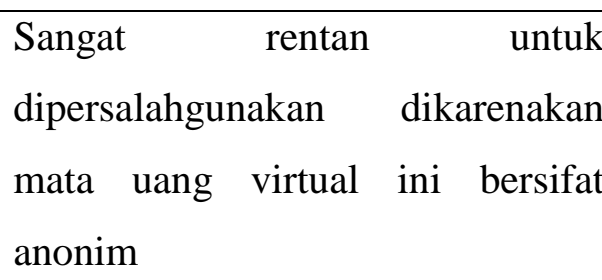 \\
\hline
\end{tabular}

Secara yuridis, pemerintah telah melarang penggunaan mata uang virtual sebagai salah satu jenis alat pembayaran. Namun, pihak pemerintah sampai detik ini belum mengeluarkan regulasi yang jelas terkait kegiatan jual-beli mata uang virtual yang terjadi di kalangan masyarakat Indonesia.

Kepastian adalah keadaan yang pasti. Hukum secara hakiki harus pasti dan adil. Pasti sebagai pedoman kelakukan dan adil karena pedoman kelakuan itu harus menunjang suatu tatanan yang dinilai wajar. Hanya karena bersifat adil dan dilaksanakan dengan pasti hukum dapat menjalankan fungsinya. Kepastian hukum merupakan pertanyaan yang hanya bisa dijawab secara normatif, bukan sosiologi. ${ }^{18}$ dan menurut Kelsen, hukum adalah sebuah sistem norma. Norma adalah pernyataan yang menekankan aspek "seharusnya" atau das sollen, dengan menyertakan beberapa peraturan tentang apa yang harus dilakukan. Norma-norma adalah produk dan aksi manusia yang deliberatif. Undang-undang yang berisi aturan-aturan yang

${ }^{18}$ Dominikus Rato, Filsafat Hukum Mencari: Memahami dan Memahami Hukum, (Yogyakarta: Laksbang Pressindo, 2010), hal.59. 
bersifat umum menjadi pedoman bagi individu bertingkah laku dalam bermasyarakat, baik dalam hubungan dengan sesama individu maupun dalam hubungannya dengan masyarakat. Aturan-aturan itu menjadi batasan bagi masyarakat dalam membebani atau melakukan tindakan terhadap individu. Adanya aturan itu dan pelaksanaan aturan tersebut menimbulkan kepastian hukum. $^{19}$

Sampai detik ini di Indonesia, belum terdapat peraturan yang secara khusus mengatur mengenai mata uang virtual. Pihak Bank Indonesia hanya menerbitkan dua buah peraturan yaitu PBI 18/40/PBI/2016 dan PBI 19/12/PBI/2017 yang secara spesifik hanya melarang penggunaan mata uang virtual sebagai alat pembayaran. Berdasarkan teori kepastian hukum diatas, terdapat kekosongan hukum mengenai mata uang virtual di Indonesia. Masyarakat tidak memiliki pedoman atas apa yang hal yang boleh dilakukan dan hal yang dilarang terhadap kehadiran mata uang virtual. Hal ini menyebabkan tidak adanya kepastian dan perlindungan hukum yang diberikan oleh pemerintah kepada masyarakat dan kedudukan hukum mata uang virtual di Indonesia masih berada dalam ranah abu-abu.

Di Indonesia, terdapat suatu jenis perdagangan komoditi yang disebut dengan perdagangan kontrak berjangka. Berdasarkan Pasal 1 Angka (1) Undang-undang Nomor 10 Tahun 2011 Tentang Perubahan Atas UndangUndang Nomor 32 Tahun 1997 Tentang Perdagangan Berjangka Komoditi, Perdagangan Berjangka Komoditi, yang selanjutnya disebut Perdagangan Berjangka, adalah segala sesuatu yang berkaitan dengan jual beli Komoditi dengan penyerahan kemudian berdasarkan Kontrak Berjangka dan Opsi atas Kontrak Berjangka. Subjek kontrak berjangka ini diatur oleh kepala Badan Pengawas Perdagangan Berjangka Komoditi.

Berdasarkan Pasal 1 Peraturan Kepala Badan Pengawas Perdagangan Berjangka Komoditi Nomor 123/BAPPEBTI/PER/08/2015 Tentang Perubahan Ketiga Atas Peraturan Kepala Badan Pengawas Perdagangan

${ }^{19}$ Peter Mahmud Marzuki, Penelitian Hukum Edisi Revisi, (Jakarta: Kencana Prenada Media Gorup, 2013), hal.158. 
Berjangka Komoditi Nomor 90/BAPPEBTI/PER/10/2011 Tentang Komoditi Yang Dapat Dijadikan Subjek Kontrak Berjangka, Kontrak Derivatif Syariah, dan/atau Kontrak Derivatif Lainnya Yang Diperdagangkan di Bursa Berjangka, komoditi yang dapat dijadikan subjek kontrak berjangka yang diperdagangkan di bursa berjangka adalah:

a. Di bidang pertanian dan perkebunan:

1. kopi;

2. kelapa sawit dan turunannya;

3. karet;

4. kakao;

5. lada;

6. mete;

7. cengkeh;

8. kacang tanah;

9. kedelai;

10. jagung;

11. kopra; dan

12. teh.

b. Di bidang pertambangan dan energi:

1. emas;

2. timah;

3. aluminium;

4. bahan bakar minyak;

5. gas alam;

6. tenaga listrik; dan

7. batu bara.

c. Di bidang industri:

1. gula pasir;

2. plywood; 
3. pulp dan kertas;

4. benang;

5. semen; dan

6. pupuk.

d. Di bidang perikanan dan kelautan:

1. udang;

2. ikan; dan

3. rumput laut.

e. Di bidang keuangan:

1. Mata uang asing; dan

2. Surat Utang Negara (SUN) Republik Indonesia.

Masyarakat Indonesia memperlakukan kegiatan jual-beli Bitcoin seperti kegiatan jual-beli emas pada umumnya. Bitcoin diperlakukan sebagai salah satu aset yang berbentuk digital yang dapat dijual maupun dibeli kapan saja, tergantung harga pasaran. Para pengguna layanan Bitcoin ini menjual aset digital mereka pada saat harganya menguntungkan bagi penggunanya. ${ }^{20}$

Dalam kegiatan jual-beli Bitcoin, resikonya sangat tinggi sekali, namun keuntungan yang didapatkan juga sangat besar. Pada awal tahun 2017, harga 1 BTC hanya sekitar 10 juta rupiah, jika dibandingkan dengan sekarang, harga 1 BTC sudah mencapai sekitar 120 juta rupiah. Apabila dulu para pengguna membeli Bitcoin pada harga yang berkisar 10 juta rupiah dan kemudian menjual Bitcoinnya sekarang, maka keuntungan yang didapatkan cukup besar.

Penulis berpendapat bahwa Bitcoin dapat dikategorikan sebagai salah satu kontrak berjangka karena kegiatan jual-beli Bitcoin merupakan investasi yang tergolong high risk high return. Hal ini didasari oleh pernyataan Bappebti, yaitu:" "Di setiap bentuk investasi selalu menghadirkan dua sisi mata uang, yakni risiko kerugian dan potensi keuntungan. Investasi di Perdagangan Berjangka Komoditi dikenal sebagai bentuk investasi yang

\footnotetext{
${ }^{20}$ Berdasarkan hasil wawancara dengan Nidya Rahmanita selaku Business Development Manager PT Indodax pada tanggal 15 Mei 2018.

${ }^{21}$ Bappebti, Perdagangan Berjangka Komoditi, (Bappebti, 2017), hal. 5.
} 
memiliki risiko tinggi sekaligus berpotensi memberikan keuntungan yang amat tinggi dalam waktu relatif singkat (High Risk High Return).”

Jika kita melihat negara Rusia, negara tersebut telah menciptakan aset digital miliknya sendiri yang dinamakan Ethereum. Teknologi cryptocurrency yang dipakai oleh Bitcoin sendiri dapat diadaptasi oleh pemerintah Indonesia untuk menciptakan sejenis aset digital seperti Ethereum. Apabila Pemerintah Indonesia dapat menciptakan aset digital lokal maka aset ini dapat diperjualbelikan pada pasar nasional maupun internasional. Jika teknologi ini telah diadaptasikan, maka hal ini dapat memperlancar transaksi aset digital dan memudahkan pengadaan pencatatan transaksi atas jual-beli aset digital di Indonesia. Harus ada aturan yang jelas yang mengatur mengenai syarat dan ketentuan bagi calon pengguna layanan ini apabila teknologi cryptocurrency ini ditetapkan di Indonesia, sehingga akan terdapat rekam jejak yang jelas atas kegiatan jual-beli aset ini. Perusahaan yang melayani jual-beli mata uang ini kemdian dapat mendaftarkan perusahaannya di Bappebti, sehinggga jika di kemudian hari terdapat transaksi yang bersifat kriminal di Indonesia, hal ini dapat diatasi dengan membuka data pengguna layanan jual-beli aset digital ini dari perusahaan yang sudah terdaftar di Bappebti. ${ }^{22}$

\section{PENUTUP}

\section{A. Kesimpulan}

Berdasarkan uraian tersebut, maka dapat disimpulkan bahwa berdasarkan Pasal 2 ayat (1) Undang-undang Nomor 7 Tahun 2011 tentang Mata Uang, disebutkan bahwa, "Mata Uang Negara Kesatuan Republik Indonesia adalah Rupiah.” Dari pengertian tersebut, maka Bitcoin tidak lah memenuhi syarat sebagai salah satu jenis mata uang di Indonesia.

Dilihat dari enam kriteria uang, Bitcoin hanya memenuhi kriteria portability dan divisibility. Hal ini disebabkan karena Bitcoin yang

\footnotetext{
${ }^{22}$ Berdasarkan hasil wawancara dengan Mariske Myeke Tampi, S.H., M.H., selaku dosen tetap Fakultas Hukum Universitas Tarumanagara pada tanggal 16 Mei 2018.
} 
dimiliki oleh setiap orang disimpan dalam sebuah dompet digital sehingga setiap pengguna layanan Bitcoin dapat dengan mudah membawa Bitcoin ini kemanapun dan dalam transaksi jual-beli Bitcoin, pengguna bebas untuk menentukan sendiri seberapa banyak jumlah Bitcoin yang ingin digunakan. Sehingga dapat disimpulkan bahwa Bitcoin tidak memenuhi kriteria uang.

Jika dilihat dari segi fungsinya, Bitcoin dapat berfungsi sebagai satuan nilai, alat tukar, dan alat penimbun kekayaan. Namun, Bitcoin tidak dapat befungsi sebagai standar pembayaran tertunda karena nilainya yang tidak stabil. Sehingga dapat disimpulkan bahwa Bitcoin juga tidak memenuhi fungsi uang.

Terkait kedudukan hukum Bitcoin di Indonesia juga belum jelas atau dapat dikatakan masih berada dalam ranah abu-abu. Hal ini disebabkan karena nihilnya regulasi yang mengatur secara spesifik mengenai Bitcoin, sehingga masyarakat tidak memiliki pedoman pasti atas apa yang diperbolehkan dan apa yang dilarang oleh pihak pemerintah.

Masyarakat Indonesia patut mendapatkan kepastian hukum dan kejelasan dari pihak pemerintahan Indonesia terkait kegiatan jual-beli Bitcoin di Indonesia. Kepastian hukum ini dapat diperoleh oleh masyarakat Indonesia apabila pemerintah merevisi dan menambahkan Bitcoin sebagai salah satu subjek kontrak berjangka yang dapat diperdagangkan pada pasar perdagangan berjangka komoditi.

\section{B. Saran}

Dengan diakuinya Bitcoin sebagai salah satu subjek kontrak berjangka dan diciptakannya aset digital lokal, maka akan terdapat aturan main yang jelas yang dapat diikuti oleh masyarakat dalam menjalankan transaksi jual-beli Bitcoin sebagai aset digital di Indonesia.

Disamping itu, pemerintah Indonesia juga dapat mengembangkan 
teknologi cryptocurrency seperti layaknya negara rusia dan menciptakan aset digital lokal sendiri. Dengan diciptakannya aset digital lokal milik Indonesia, maka masyarakat Indonesia dapat melaksanakan kegiatan jual-beli aset digital lokal dan memajukan roda perekonomian Indonesia.

Oleh sebab itu, diperlukan peraturan yang secara jelas mengatur kedudukan hukum Bitcoin sebagai salah satu subjek kontrak berjangka yang dapat diperjualbelikan dalam Perdagangan Kontrak Berjangka di Indonesia. Dengan terciptanya peraturan tersebut, masyarakat akan mendapatkan kepastian dan perlindungan hukum atas kegiatan jual-beli Bitcoin.

\section{DAFTAR PUSTAKA}

\section{A. Buku-buku}

Goldfield, Stephen M. dan Lester V. Chandler. Ekonomi Uang dan Bank. (Jakarta: Erlangga, 1990).

Iswardono SP. Uang dan Bank. Edisi ke-4. (Yogyakarta: BPFEYogyakarta, 1991).

Marzuki, Peter Mahmud. Penelitian Hukum Edisi Revisi. (Jakarta: Kencana Prenada Media Group, 2013).

Pratama, Rahardja. Uang dan Perbankan. (Jakarta: Rineka Cipta, 1990).

Rato, Dominikus. Filsafat Hukum Mencari: Memahami dan Memahami Hukum. (Yogyakarta: Laksbang Pressindo, 2010).

Strader, Troy J. Digital Products, Management, Technology, and Practice. (Pennsylvania: Business Science Reference, 2010).

Subekti. Pokok-pokok Hukum Perdata. Cetakan ke-20. (Jakarta: Intermasa, 1985).

Widjaja, Gunawan dan Kartini Muljadi. Kebendaan Pada Umumnya. Cetakan ke-1. (Jakarta: Kencana Prenada Media Group, 2003).

\section{B. Peraturan Perundang-undangan}


Indonesia. Kitab Undang-Undang Hukum Perdata.

. Undang-Undang Nomor 7 Tahun 2011 tentang Mata Uang

(Tambahan Lembaran Negara Republik Indonesia Nomor 5223).

. Undang-undang Nomor 10 Tahun 2011 Tentang Perubahan

Atas Undang-Undang Nomor 32 Tahun 1997 Tentang

Perdagangan Berjangka Komoditi. (Tambahan Lembaran

Negara Republik Indonesia Nomor 5232).

. Peraturan Bank Indonesia Nomor 18/40/PBI/2016 tentang

Penyelenggaran Pemrosesan Transaksi Pembayaran.

. Peraturan Bank Indonesia Nomor 19/12/PBI/2017 tentang

Penyelenggaraan Teknologi Finansial.

. Peraturan Kepala Badan Pengawas Perdagangan Berjangka

Komoditi Nomor 123/BAPPEBTI/PER/08/2015 Tentang

Perubahan Ketiga Atas Peraturan Kepala Badan Pengawas

Perdagangan Berjangka Komoditi Nomor

90/BAPPEBTI/PER/10/2011 Tentang Komoditi Yang Dapat

Dijadikan Subjek Kontrak Berjangka, Kontrak Derivatif Syariah,

dan/atau Kontrak Derivatif Lainnya Yang Diperdagangkan di Bursa Berjangka.

\section{Makalah Ilmiah}

Bappebti. Perdagangan Berjangka Komoditi. 2017.

IMF Staff. Virtual Currencies and Beyond: Initial Considerations. Januari 2016

Ryan Farell. An Analysis of the Cryptocurrency Industry. May 2015.

D. Artikel Internet

Anonim. "Pertanyaan yang Sering diajukan". https://bitcoin.org/id/faq\#penambangan. 2018.

. "Siaran Pers". https://www.bi.go.id/id/ruang-media/siaranpers/Pages/sp_200418. 13 Januari 2018. 
Indodax. “Apa Itu Indodax.com?”. https://help.indodax.com/apa-ituindodax-com/. 2018.

Joshi, Divya. "List of top Virtual Currencies in 2017 and What Differentiates Them". http://www.businessinsider.com/list-topcryptocurrenciesanalysis-comparison-2017-10/?IR=T. 19 Oktober 2017.

Rakhma, Sakina. "Nilai Terus Menguat, Pengguna Bitcoin Indonesia Meningkat".

http://ekonomi.kompas.com/read/2017/12/04/153000626/nilaiterus-menguat-pengguna-bitcoin-Indonesia-meningkat.

Desember 2017.

\section{E. Wawancara}

Rahmanita, Nidya. Wawancara dengan penulis. PT Indodax. 15 Mei 2018.

Tampi, Mariske Myeke. Wawancara dengan penulis. Fakultas Hukum Universitas Tarumanagara. 16 Mei 2018. 